\title{
Black pools of death: hypoxic, brine-filled ice gouge depressions become lethal traps for benthic organisms in a shallow Arctic embayment
}

\author{
R. G. Kvitek ${ }^{1, *}$, K. E. Conlan ${ }^{2}$, P. J. Iampietro ${ }^{3}$ \\ ${ }^{1}$ Institute for Earth System Sciences \& Policy, California State University Monterey Bay, Seaside, California 95039, USA \\ ${ }^{2}$ Canadian Museum of Nature, PO Box 3443, Station D, Ottawa, Ontario, Canada K1P 6P4 \\ ${ }^{3}$ Moss Landing Marine Labs, Moss Landing, California 95039, USA
}

\begin{abstract}
Numerous small $\left(9 \pm 7 \mathrm{~m}^{2}\right.$, mean $\pm \mathrm{SD}$ ) depressions filled with dark water were found covering $14 \%$ of the shallow ( $<10 \mathrm{~m}$ ) sea floor of Resolute Bay, NWT, Canada, on July 28, 1995. The water in these black pools was hypoxic, warmer, and more saline and sulfide rich than surrounding bottom water. These pools also contained high numbers of dead epibenthic species, including: shrimps, amphipods, mysids, bivalves, gastropods, sea cucumbers, and fishes. Infaunal abundance and biomass, as well as benthic chlorophyll concentrations, were significantly lower inside the black pools than in the surrounding sediments. The pools persisted until the first strong wind to occur after annual sea-ice break-up. A year later (July 1996), sulfide-rich black saline pools were again found in the same depressions as well as in new depressions formed by grounding ice during the previous summer. We hypothesize that the pools form annually, as the sea ice expels dense brine, which sinks and collects in previously formed ice gouge depressions on the shallow slopes of Resolute Bay. Benthic respiration would be sufficient to drive the stratified water in the pools to anoxia in the absence of currents and turnover, resulting in microbial production of highly toxic sulfides. Once established, the pools persist as lethal traps for benthic and demersal organisms until dispersed by wind or waves after breakup of the annual ice cover.
\end{abstract}

KEY WORDS: Brine pools - Ice scour - Anoxia - Arctic - Benthos - Disturbance - Mortality · Polar

\section{INTRODUCTION}

Hypoxic and anoxic seafloor brine pools have been found associated with seeps and evaporite deposits along lower continental shelves and slopes (Shokes et al. 1977, Brooks et al. 1779, Bright et al. 1980, Harper et al. 1981, Hovland \& Judd 1988, Cary et al. 1989, MacDonald et al. 1990, MacDonald \& Fisher 1996). Many of these sites support bacterial mats (Diaz \& Rosenberg 1995), and some have been persistent enough to support chemosynthetic invertebrate communities (MacDonald et al. 1990, MacDonald \& Fisher 1996). Behavioral changes and mortality observed in epibenthic and demersal species, including fishes and shrimps, have

·E-mail: rikk_kvitek@monterey.edu been attributed to the hypersaline and hydrogen sulfide rich water found in these pools (MacDonald 1992, Diaz \& Rosenberg 1995, MacDonald \& Fisher 1996).

Seafloor brine pools have also been reported from bays and shallow continental shelves in the Arctic (Lewis 1981), resulting from shallow water brine drainage. Such brine in high latitudes is produced by expulsion from sea ice during desalination in the winter and spring, resulting in a rain of dense, saline water sinking and running downslope (Ackley \& Sullivan 1994, Cavalieri \& Martin 1994). In an enclosed bay or fjord, the sinking brine can produce a stable pycnocline which may resist mixing for months or years and lead to anoxic bottom waters in these deep water catchment basins (Gallagher \& Burton 1988).

Here we describe the physical and chemical properties, biological consequences, and recovery chronology 
of ephemeral hypoxic brine pools found in the shallows of a high latitude, protected embayment. These pools form in shallow seabed depressions created by grounding ice, and may represent a seasonally recurrent, synergistic interaction between seafloor ice scour and brine drainage from the sea ice overhead.

\section{STUDY SITE DESCRIPTION AND INITIAL FIELD OBSERVATIONS}

Resolute Bay, NWT, Canada, is a shallow ( $<35 \mathrm{~m}$ ) embayment protected by a sill that rises to $10 \mathrm{~m}$ depth at the mouth (Fig. 1). Floating ice with keel drafts less

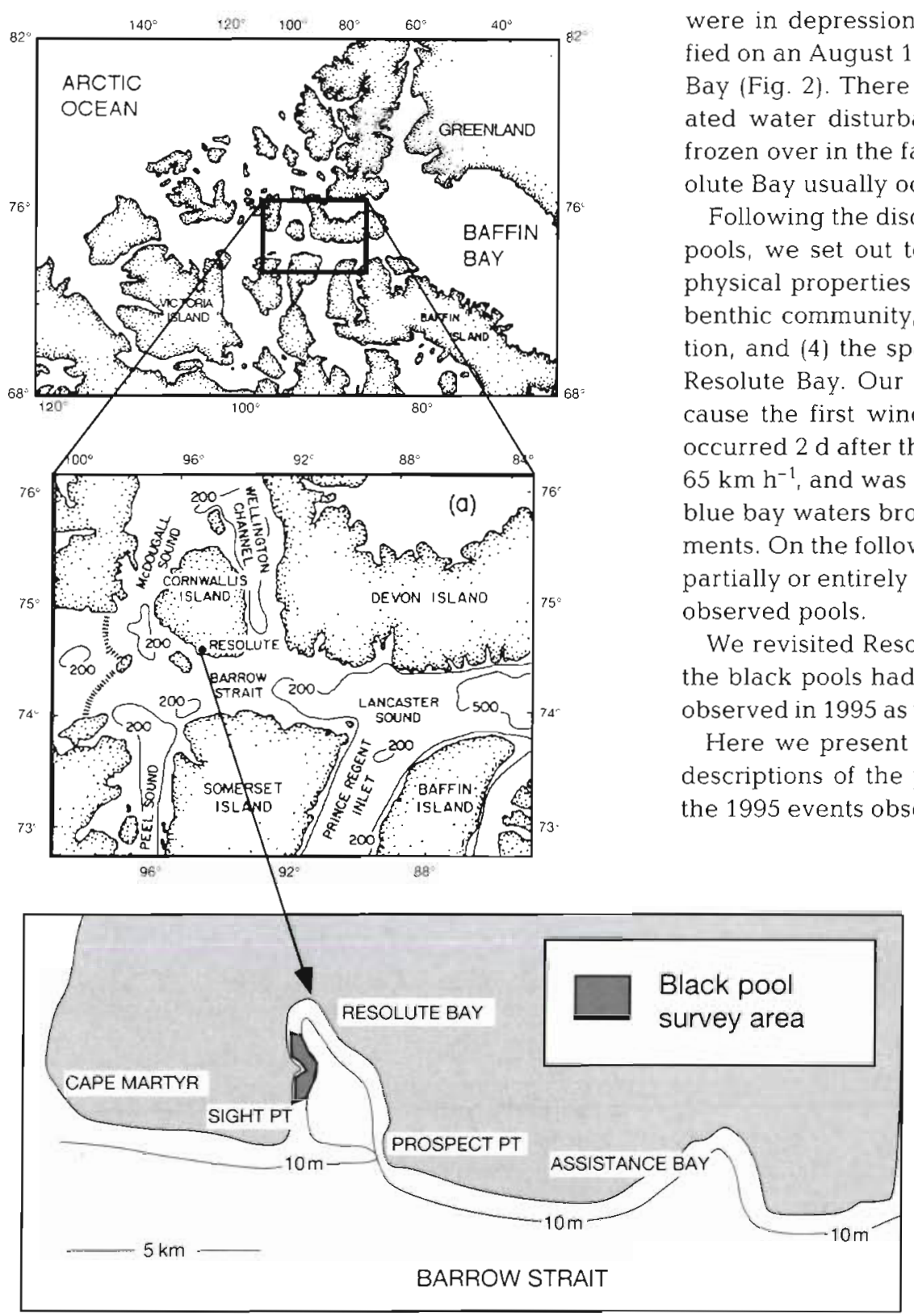

than $10 \mathrm{~m}$ can enter and ground on the shallow flanks of the bay. These groundings have produced a pockmarked zone of ice gouge depressions above the $10 \mathrm{~m}$ depth contour (Fig. 2). There are no tidal currents in the bay and, in the absence of wind or swell, no measurable water movement (Welch et al. 1997, Kvitek et al. unpubl.).

On July 28, 1995, we discovered numerous pools of black water filling shallow depressions in the sea floor above the $10 \mathrm{~m}$ depth contour in Resolute Bay (Fig. 3). These pools were ringed with white bacterial mats, and contained large numbers of dead benthic and epibenthic organisms. Drainage pathways leading from the off-shore edge of many pools were also edged with dense, white, bacterial mats. Several of the pools were in depressions that had been previously identified on an August 1994 sidescan sonar map of Resolute Bay (Fig. 2). There had been no wind or wave generted water disturbance in Resolute Bay since it had lute Bay usually occurs in June-July.

discovery of these shallow-water black benthic community, (3) the mechanism of pool formaion, and (4) the spatial extent of this phenomenon in Resolute Bay. Our quick response was fortuitous, because the first wind storm of the open water season occurred $2 \mathrm{~d}$ after the discovery. Wind speed exceeded $\mathrm{km} \mathrm{h}^{-1}$, and was strong enough to turn the normally ery the black water had been bserved pools.

We revisited Resolute Bay in July 1996 to verify that the black pools had reformed in the same depressions bserved in 1995 as well as in newly created ice gouges. Here we present physical, chemical, and biological descriptions of the pools, and a 2.5 wk chronology of the 1995 events observed. Additionally, we offer a con-

Fig. 1. Location of the Resolute Bay, NWT, study site in the Canadian Arctic Archipelago. Hatching indicates the area in which black hypoxic brine pools were found in July 1995. No black pools were found below the $10 \mathrm{~m}$ depth contour 


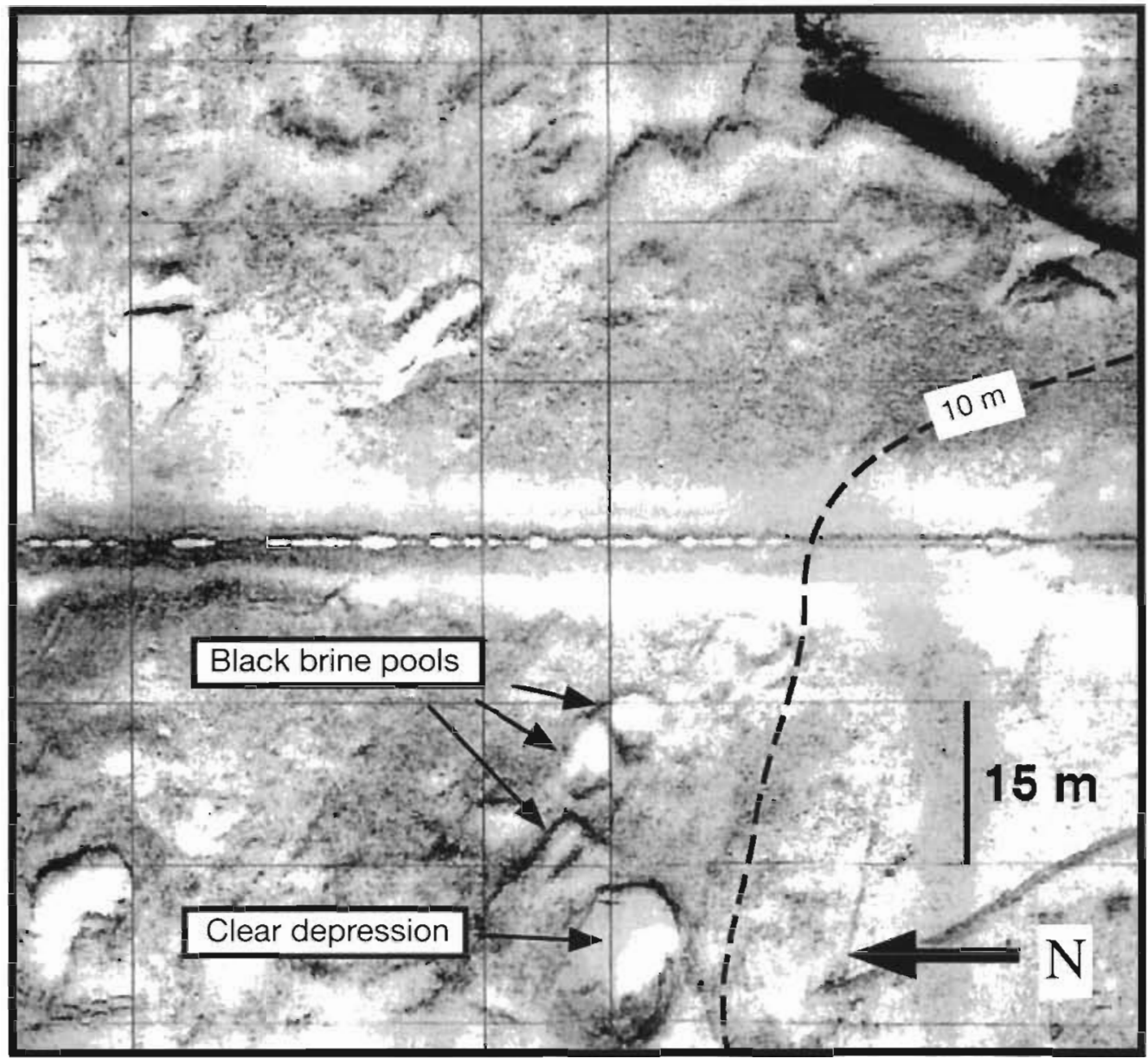

Fig. 2. A sidescan sonar record from Resolute Bay, NWT, Canada, in August 1994, showing a plan view of the sea floor with the same ice scour depressions that were found to contain black hypoxic brine pools on July 28, 1995. Also shown is a larger ice scour depression that did not contain black, hypersaline or hypoxic water in 1995. No depressions or black pools were found below the $10 \mathrm{~m}$ depth contour (area to the right of the contour line)

ceptual model describing the proposed interaction between ice gouging and brine formation that would produce an annual cycle of pool formation, biotic impact, and partial recovery. We propose a process whereby the habitat modification from a single episodic disturbance (ice gouging) can concentrate the ecological impact of an otherwise diffuse seasonal event (sea-ice desalination), thereby initiating an annual cycle of benthic mortality and recovery.

\section{METHODS}

Because our discovery of the brine pools in Resolute Bay in July 1995 was unexpected, we made use of equipment on hand to describe and quantify this phenomenon. For the 1996 field season we obtained instruments enabling more rigorous sampling of pool sulfide concentrations.
Our general approach compared and contrasted the conditions found in the black pools with those found both on the adjacent seabed and in nearby 'clear depressions' that did not contain discolored water. The clear depressions differed from the black pool depressions in being completely surrounded by berms of sediment pushed up by grounded ice. During 1995, we determined the seafloor position of all sampling sites and pools within $\pm 2 \mathrm{~m}$ using Differential GPS (global positioning system) along a $300 \mathrm{~m}$ section of the Resolute Bay shore (Fig. 1) and marked sampled pools with PVC stakes. In 1996, we relocated 10 of the staked 1995 black pool depressions. All relocated pools contained black water. In addition, we found several new black pools occupying new ice gouge depressions formed after the start of the 1995 study season.

Divers used quantitative video surveys in 1995 to determine spatial distribution and size of the black pools, as well as percentage of the seafloor covered by 

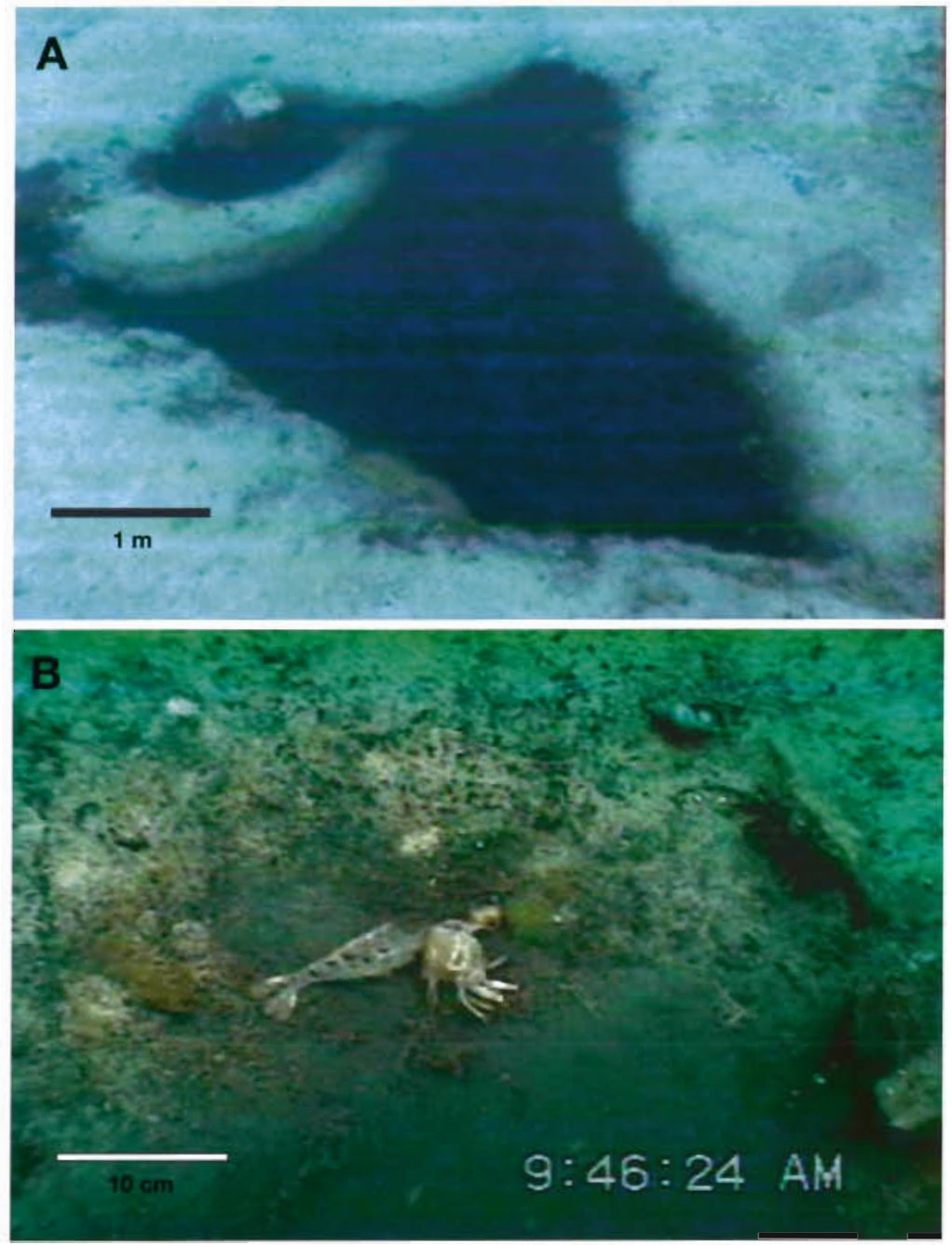

Fig. 3. Video image of $(A)$ an undisturbed black pool, and $(B)$ dead shrimp and gastropod in a flushed black pool

pools. Video transects were run at a constant speed of $0.8 \pm 0.03 \mathrm{~m} \mathrm{~s}^{-1}$ (mean $\pm \mathrm{SD}$ ) at $1 \mathrm{~m}$ above the seabed using a Sony Hi-8 video camera mounted on a Dacor Sea Sprint ${ }^{\circledR}$ scooter. Each transect covered a $40 \times 2 \mathrm{~m}$ swath of seabed, and was haphazardly placed below $(n=3)$ or above $(n=3)$ the 10 m contour line. Percent of the seabed covered by black pools was calculated by dividing the length of time a point on the lower edge of the video frame crossed pools by the total run time on each transect. Additional video surveys were run periodically to characterize qualitative changes associated with the depressions from July 28 through August 16,1995 . No video. surveys or quadrats were done in 1996 due to poor visibility.

Sizes of 8 pools before and after the wind storm of July 30, 1995, were calculated using vertical video images encompassing entire pools and a $1 \mathrm{~m}$ scale bar.
These images were captured as digital frame grabs, and imported into an image analysis program (NIH Image v1.58) to outline the perimeter and calculate the area of each pool. Divers measured the maximum depths of the black water in 7 pools with a meter stick.

Water column profiles were measured in 1995, at $0.5 \mathrm{~m}$ intervals from the seabed to a height of $5 \mathrm{~m}$, with a hand-held Aquacheck Water Analyzer (Industrial Chemical Measurement model no. 51601) with a CTD-DO $\mathrm{DO}_{2}$ sensor. Measurements were made in 3 black pools, 3 clear depressions, and at 3 flat, undisturbed (reference) sites adjacent to the black pools. Water samples were also taken from the black pools and reference sites using $250 \mathrm{ml}$ Nalgene ${ }^{\circledast}$ bottles in 1995 and syringes in 1996. The 1995 water samples were frozen, returned to Moss Landing Marine Laboratories 2 mo later and used to calibrate the conductivity values obtained from the CTD, as well as for sulfide concentration analysis. The long delay in sulfide analysis for the 1995 samples was due to the lack of laboratory facilities in the field. As a result, we expect our 1995 sulfide values to be a very conservative estimate of the actual hydrogen sulfide concentrations present at the time of sampling. Water samples taken in 1996 , however, were analyzed within $1 \mathrm{~h}$ for total sulfides (Aquaquant ${ }^{\circledR}$ 14416, detection limit $=0.02 \mathrm{mg} \mathrm{l}^{-1}$ ) and salinity (Atago 2441 refractometer)

Faunal impacts of the black pools were evaluated in 2 ways during 1995. Epifaunal victims were identified and quantified from 160 video quadrats of $0.1 \mathrm{~m}^{2}$ taken from 18 individual pools and 57 quadrats taken at 3 reference sites within the black pool zone. Divers took the pool quadrats at equally spaced intervals along parallel paths swum over the entire pool. Divers blindly placed quadrats haphazardly along a straight path at each reference site. A constant area of view was maintained using a bi-pod system to hold the video camera a preset distance above the seafloor. Infaunal samples were taken with hand-held corers $\left(0.0075 \mathrm{~m}^{2}\right)$ from 6 black pools, 6 reference sites, and 3 clear depressions. Cores were taken to a depth of $15 \mathrm{~cm}$ and the portion retained on a 0.5 mm screen was fixed in 10\% formalin-seawater and preserved in $70 \%$ glycerated ethanol. Fauna, sorted and identified to lowest possible taxonomic level, were enumerated and weighed. 
The black pools also appeared to inhibit the development of benthic diatoms that generally form a uniform golden film on the sediment surface of Resolute Bay. For this reason, we evaluated benthic chlorophyll concentrations, and diatom species composition and abundance. Benthic chlorophyll was measured inside and outside of black pool depressions before and $17 \mathrm{~d}$ after flushing of the black water in 1995. Divers collected benthic diatoms and sediment using $5 \mathrm{~cm}$ diameter Plexiglas benthic cores. The diatom cores were transported to the lab in racks placed in a cool, dark, ice chest. The cores were left in the cooler for a minimum of $3 \mathrm{~h}$ to allow all material disturbed during collection to settle. Once material had settled, diatoms were siphoned from the sediment surface using a glass pipette, rubber hose, and vacuum pump until all water in the core was removed. The diatom/sea water solution was thoroughly mixed in an electric blender at low speed for $5 \mathrm{~s}$ to homogenize the mixture. The volume of the mixture was measured and then four $10 \mathrm{ml}$ subsamples were taken using an Oxford Macroset pipette. One of the subsamples was preserved with Lugol's solution for later diatom identification while the remaining 3 subsamples were prepared for chlorophyll analysis. These 3 subsamples were filtered onto GFF glass filters. The GFF filters were placed into $10 \mathrm{ml}$ of $90 \%$ acetone in glass scintillation bottles for chlorophyll extraction. The acetone/filter mixture was placed in a freezer for $24 \mathrm{~h}$. Chlorophyll and phaeopigment (after acidification with $\mathrm{HCl}$ ) concentrations were then measured using a Turner 10AU fluorometer.

Divers collected sediment cores for benthic diatom species composition and abundance analysis on August 5,6 , and 16, 1995. These samples were taken from 3 types of sites: (1) the few remaining black pools found in the area following the initial flushing event, (2) the golden brown halos observed to be developing on the surface sediments around depressions formerly occupied by black pools, and (3) reference sites. Diatom samples were preserved in 1 to $2 \%$ acidified Lugol's solution (Sournia 1978). Subsequently $10 \mathrm{ml}$ subsamples were digested using an $\mathrm{H}_{2} \mathrm{SO}_{4}: \mathrm{HNO}_{3}$ solution and washed at least 5 times with distilled water. Subsamples of 1 to $2 \mathrm{ml}$ from the acid-digested material were dried onto \#1 $18 \mathrm{~mm}^{2}$ coverslips and mounted to microscope slides using Hyrax. Six hundred valves per sample were identified using the standard procedures outlined by Lund et al. (1958) and Sournia (1978).

Data were analyzed using parametric statistical tests where appropriate. Non-parametric tests were used where parametric statistics were precluded by heteroscedasity of data or other assumption violations.

\section{RESULTS}

Black pools were found only above the $10 \mathrm{~m}$ depth contour, where they covered $13.7 \pm 6.5 \%$ (mean $\pm \mathrm{SD}$ ) of the sea floor. Maximum pool depth averaged $0.32 \pm$ $0.12 \mathrm{~m}$ (mean $\pm \mathrm{SD}, \mathrm{n}=7$ ). Mean pool size $\left(8.6 \pm 6.9 \mathrm{~m}^{2}\right)$ before water column mixing by the July 30,1995 , storm was significantly greater than pool size after mixing $\left(3.4 \pm 4.0 \mathrm{~m}^{2}\right)$ (paired $t$-test, $t=3.0, \mathrm{df}=7, \mathrm{p}=0.02$ ). Table 1 lists the changes that were observed in the video surveys of the black pools over the study period.

Water within the black pools differed significantly in many characteristics from that in clear depressions and at reference sites (ANOVA and Fisher PLSD multiple comparison tests, $n=3, p<0.0001$ ) (Fig. 4) Water in the black pools was hypoxic, warmer, more saline, and denser than overlying water in 1995. On average, dissolved oxygen was $10 \mathrm{mg} \mathrm{l}^{-1}$ less, temperature was $3.5^{\circ} \mathrm{C}$ higher, salinity was 5.5 ppt higher, and density was $0.005 \mathrm{~g} \mathrm{~cm}^{-3}$ higher in the black pools. Sulfide levels in 4 black pools in 1995 averaged $0.07 \pm$ $0.05 \mathrm{mg} \mathrm{l}^{-1}$, while levels at 4 reference sites were below the detection limit of $0.01 \mathrm{mg} \mathrm{l}^{-1}$. At the time of sampling, water taken from the black pools smelled much more intensely of hydrogen sulfide than at the time of analysis.

Sulfide concentrations in 1996 were also significantly higher inside black pools $\left(9.3 \pm 10.7 \mathrm{mg} \mathrm{l}^{-1}, \mathrm{n}=\right.$ 12) than at reference sites (below $0.02 \mathrm{mg} \mathrm{l}^{-1}$ detection limit, $\mathrm{n}=3$ ) (Mann Whitney $U$-test, $\mathrm{p}=0.03$ ). Black pools were significantly more saline as well in 1996 than reference sites (mean $\pm \mathrm{SD}$ of $38.6 \pm 5.9, \mathrm{n}=12$ vs $32.7 \pm 0.6, \mathrm{n}=3$ respectively) (Mann Whitney $U$-test, $\mathrm{p}=0.01$.

Dead benthic organisms found associated with the black pools in 1995 and 1996 included shrimps, amphipods, mysids, bivalves, gastropods, sea cucumbers, and fishes. Species accounting for the majority of the victim biomass were the infaunal bivalves Mya truncata Linnaeus and Serripes groenlandicus (Bruguière), buccinid snails (variously Buccinum hydrophanum Hancock, B. glaciale Linnaeus, and B. finmarkianum Verdrüzen), and 2 types of shrimp [Sclerocrangon boreas (Phipps) and Lebbeus spp.]. This pattern was quantified in 1995 . Victims from all taxonomic groups were significantly more abundant in black pool versus the reference site video quadrats (Mann-Whitney $U$-test, $\mathrm{p} \leq 0.05$ ). Only a single dead S. groenlandicus was identified in the 57 reference site video quadrats taken in 1995 (Fig. 5).

Infaunal sediment cores taken in the reference sites during 1995 and 1996 captured an abundant and diverse fauna (Fig. 6). The large bivalves Mya truncata and Serripes groenlandicus dominated in biomass. Other smaller, but abundant bivalves were Astarte 
spp. [variously A. borealis (Schumacher), A. cf. montagui (Dillwyn), and A. cf. warhami (Philippi)], Axinopsida orbiculata (G, O. Sars), and Macoma spp. [variously $M$. calcarea (Gmelin), M. loveni (Steenstrup), and $M$. moesta [Deshayes)]. The gastropods Retusa obtusa (Montagu) and Oenopota sp. were frequently found as well. Polychaetes were numerically the most abundant, dominated by diverse spionid, sabellid, capitellid, cirratulid, and syllid species. Cumaceans, podocopid ostracods, and the amphipods Orchomene minutus (Kröyer) and Monoculodes spp. burrowed in the sediment surface. Mites, nemerteans, and burrowing cucumbers and priapulids were also abundant. These fauna were virtually absent in the black pools, where only a few mites, amphipods, and polychaetes were found alive (Fig. 6). Unlike the black pools, the clear depression sediments (sampled only during 1995) held crustaceans, polychaetes, gastropods, and bivalves, although in significantly lower numbers than in the reference sediments (Fig. 6). Only the scavenging amphipod $O$. minutus and the micropredaceous amphipods Monoculodes vibei Just and M. latimanus (Goes) were equally or more abundant inside the clear depressions than outside. Infaunal biomass reflected these patterns of abundance, with the reference sites being the highest, the black pools the lowest, and the clear depressions intermediate (Fig. 6b). All differences between sites were significant for each year (KruskalWallis $\mathrm{p}<0.02$, and Mann-Whitney $U$-test, $\mathrm{p}<0.002$ ).

Benthic diatom biomass, as indicated by phaeopigment-corrected chlorophyll concentrations, was significantly lower on sediments in black pools than on sediments adjacent to the pools (1-tailed $t$-test, $t=1.84$, $\mathrm{df}=7, \mathrm{p}=0.05$ ) (Fig. 7). Seventeen days after flushing in 1995, however, chlorophyll concentrations inside former black pool depressions were not significantly different from reference sites ( 1 -tailed $t$-test, $t=1.00$, $\mathrm{df}=10, \mathrm{p}=0.83$ ) (Fig. 7)

The epiphytic diatoms Cocconeis spp. and tube dwellers Berkleya rutilans (Trentepohl) Grunow and Navicula sp. were more abundant in samples collected inside of the pool depressions in 1995. The golden halo around the edge of the depressions also had greater numbers of Cocconeis, Stauroneis sp. 1, Trachyneis aspera (Ehrenberg) Cleve and Pinnularia quadratarea (Schmidt) Cleve. The taxa $P$. quadratarea and $T$. aspera also appeared in higher numbers at the outside reference sites. Genera present at all sites (>5\% abun-

Table 1 Chronology of events and seafloor observations following the July 28, 1995, discovery of black, hypoxic, brine pools on the floor of Resolute Bay, NWT, Canada

\begin{tabular}{|c|c|c|}
\hline Date & Environmental conditions & Seafloor observations of black pools \\
\hline July $28-29$ & $\begin{array}{l}\text { Resolute Bay free of ice for } \\
2 \text { wk. No wind since spring } \\
\text { break-up. No water motion } \\
\text { or currents. Bay surface } \\
\text { water is clear and blue }\end{array}$ & $\begin{array}{l}\text { Divers discover and sample seafloor depression filled with hypoxic brine and } \\
\text { containing many dead benthic organisms. Water in pools } 3.5^{\circ} \mathrm{C} \text { above ambient. } \\
\text { Many of the pools rimmed by a sharply defined halo of dense, white, bacterial } \\
\text { mats }\end{array}$ \\
\hline July 30 & $\begin{array}{l}\text { First wind storm (> } 35 \text { knots) } \\
\text { since the beginning of } \\
\text { open water. White caps on } \\
\text { Resolute Bay. Bay surface } \\
\text { water becomes opaque and } \\
\text { brown from resuspended } \\
\text { bottom sediments }\end{array}$ & Diving operations curtailed due to high winds \\
\hline July 31 & $\begin{array}{l}\text { Calm conditions return. No } \\
\text { wind or swell }\end{array}$ & $\begin{array}{l}\text { Dark water now absent or greatly reduced in previously sampled seafloor depres- } \\
\text { sions. Early in the day, bottom sediments in depressions are very black with surface } \\
\text { dusting of fine light colored sediments. Sediments become progressively lighter in } \\
\text { color throughout the day. Many victims previously covered by the dark brine now } \\
\text { exposed to numerous scavenging lyssianasid amphipods and buccinid gastropods }\end{array}$ \\
\hline August 2 & No wind or swell to date & $\begin{array}{l}\text { Water in some of the deeper depressions begins to turn black again. Victims not } \\
\text { consumed by scavengers are becoming colonized by white bacterial fuzz. Scav- } \\
\text { engers do not attack bacteria-covered victims }\end{array}$ \\
\hline August 5 & No wind or swell to date & $\begin{array}{l}\text { Shallower depressions becoming less distinct, generally covered with a golden } \\
\text { brown layer of diatoms and have only a few patches of black surface sediments } \\
\text { showing. White bacterial cover on victims increases in these shallow depressions. } \\
\text { Water in deeper pools continues to darken. White bacterial cover does not grow } \\
\text { on victims covered by the dark water in these deeper pools }\end{array}$ \\
\hline August 8 & No wind or swell to date & All trends continue \\
\hline August 15 & No wind or swell to date & $\begin{array}{l}\text { Only deepest depressions contain dark water. All other depressions covered by } \\
\text { golden brown diatom layer and, apart from topography and victims, are visually } \\
\text { indistinguishable from surrounding sea floor }\end{array}$ \\
\hline
\end{tabular}




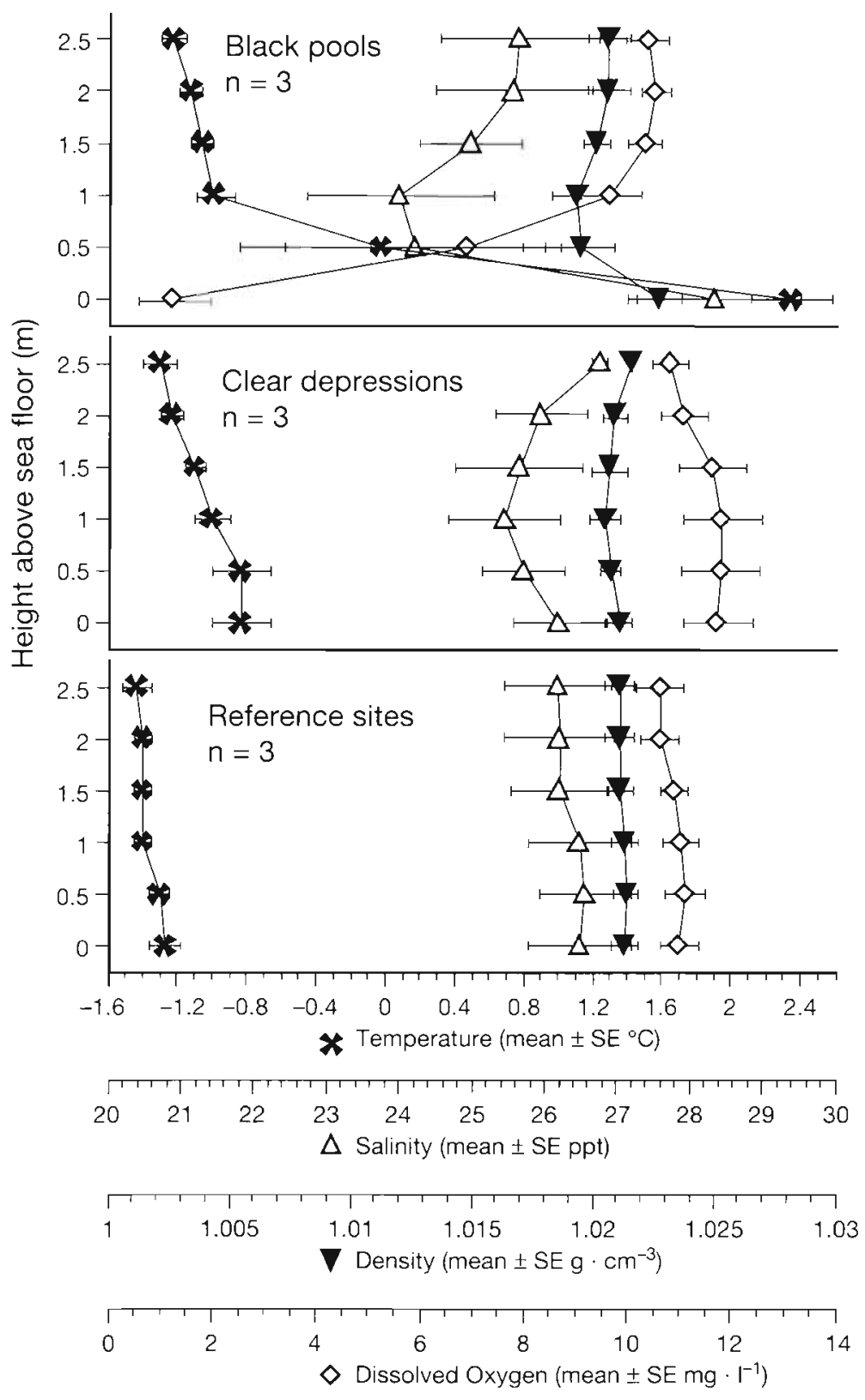

Fig. 4. Vertical water column profiles for 1995 black pools, clear depressions, and reference sites in Resolute Bay, NWT, Canada. Values are mean $\pm \mathrm{SE}$ for temperature, salinity, density, and dissolved oxygen taken at $0.5 \mathrm{~m}$ height intervals above the sea floor

dance) included Amphora, Fragilaria, Navicula, Nitzschia and Tryblionella. Comparing the dead and live flora from the center of the black pool depressions with the edge and outside reference sites using Euclidean distance (single linkage) clustering revealed that all the black pool samples except one and the edge sites had poor floral associations with each other and with the outside reference sites. On the other hand, 6 of the 8 outside reference sites had similar floristic associations.

\section{DISCUSSION}

The seasonal accumulation of sea-ice brine in ice gouge depressions is a plausible explanation for the annual formation of shallow-water Arctic brine pools. We present our conceptual model of annual disturbance below and in Fig. 8 .

During open water periods, floe ice with drafts less than $10 \mathrm{~m}$ cross the sill of Resolute Bay (Fig. 1). When driven ashore by wind, this ice grounds on the flanks of the bay, producing a pockmarked zone of depressions above the $10 \mathrm{~m}$ contour (Figs. $2 \& 8_{1}$ ). During the winter months, brine is expelled from the annual sea ice, producing a rain of sinking water (Cavalieri \& Martin 1994). In the pockmarked shallows of Resolute Bay, this brine runs downslope, collecting in the depressions left by the grounding ice (Fig. $8_{2}$ ). The dense brine in these depressions remains isolated from the overlying water, because ice cover prevents mixing of the water column by wind and swell, and there are no tidal currents in Resolute Bay (Welch et al. 1997, Kvitek et al. unpubl.) (Fig. $8_{3}$ ). The clear depressions are protected from the brine flow by their continuous, high berms and so do not become stratified and hypoxic. From previously measured values for benthic respiration in Resolute Bay $\left(0.336 \mathrm{~g} \mathrm{O}_{2} \mathrm{~m}^{-2} \mathrm{~d}^{-1}\right)$, the pools could go anoxic in approximately $15 \mathrm{~d}$ in the absence of mixing (Welch \& Kalff 1975 , Welch et al. 1997) (Fig. 84). Hypoxia or anoxia then leads to the deaths of sessile species unable to escape or extend above the anoxic layer (Harper et al. 1981) (Fig. 85). Their deaths further increase the organic material available for anaerobic bacterial. metabolism and the subsequent production of highly toxic hydrogen sulfide (Faganeli et al. 1985) (Fig. 86).

The combined effects of hypersalinity, hypoxia, and hydrogen sulfide account for the high concentrations of dead epifaunal and demersal species in the brine pools (Diaz \& Rosenberg 1995) (Fig. ${ }_{7}$ ). Brine seeps in deep water habitats generate similar lethal traps for demersal species such as fishes and shrimps (MacDonald 1992, MacDonald \& Fisher 1996). Unlike the deep brine seeps, however, the pools in Resolute Bay are well within the photic zone. Their elevated temperatures may be the result of radiant solar energy heating the black water and being retained below the steep pycnocline at the surface of 


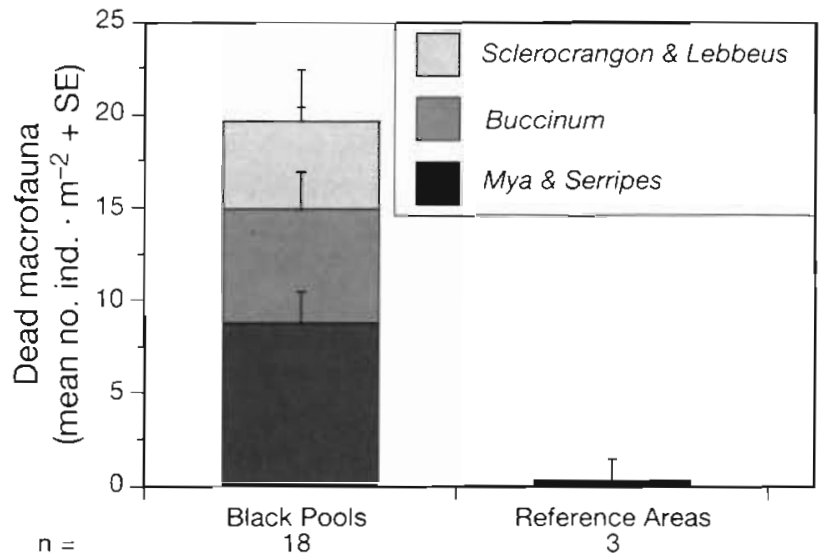

Fig. 5. Abundance of dead macrofauna identified in 1995 video quadrats of black pools and reference seafloor sites in Resolute Bay. Dead clams (Mya truncata and Serripes groenlandicus), gastropod snails (Buccinium spp.) and shrimps [Sclerocrangon boreas (Phipps) and Lebbeus spp.] were significantly more abundant in the black pools $(171$ quadrats among 18 black pools) than on the reference sea floor, where only a single dead $S$ groenlandicus was identified in 57 quadrats at 3 reference sites. ( $n=$ total number of sites sampled)

the pool (Fig. 4). This same mechanism has been used to explain the inverted thermoclines in ice covered meromictic Antarctic lakes (Hoare 1966, Bydder \& Holdsworth 1977). Similar pockets of anoxia have been found in depressions amongst mosses at 3 to $19 \mathrm{~m}$ depth in Char Lake, near Resolute Bay (Welch \& Kalff 1974). These patches were 0.2 to $0.4 \mathrm{~m}$ deep, anoxic, and milky all winter and early spring. Downslope spillage paths were evident as strips of blackened moss. These depressions went anaerobic in as little as 1 mo after the onset of the winter dark season, at a metabolic rate of $0.24 \mathrm{~g} \mathrm{O}_{2} \mathrm{~m}^{-2} \mathrm{~d}^{-1}$ in a stable water mass less than $0.5 \mathrm{~m}$ thick.

The hypoxic conditions in the Resolute Bay black pools are also likely to be responsible for the observed differences in the benthic diatom community. Although dead siliceous diatoms dominated the flora at all sites sampled, the accumulation of dead forms can be expected due to the persistent nature of the silicate shells. The black pool depressions, however, contained very few living diatoms and very low chlorophyll concentrations (Fig. 7). Furthermore, the poor floristic associations at the inside and edge of the black pool depressions highlights their difference from the more homogeneous outside reference seabed. Interestingly, other species of mucilage-forming algae (e.g. Zygnema spp. and Zygogonium spp.) have been shown to live in harsh environments by recycling carbon ( $\mathrm{H}$. Vandermeulen pers. comm.). Therefore, tube dwelling diatoms such as Navicula sp. and Berkleya rutilans, 2 of the dominant species in the black pool depressions, may be able to persist longer than other species under low oxygen conditions.

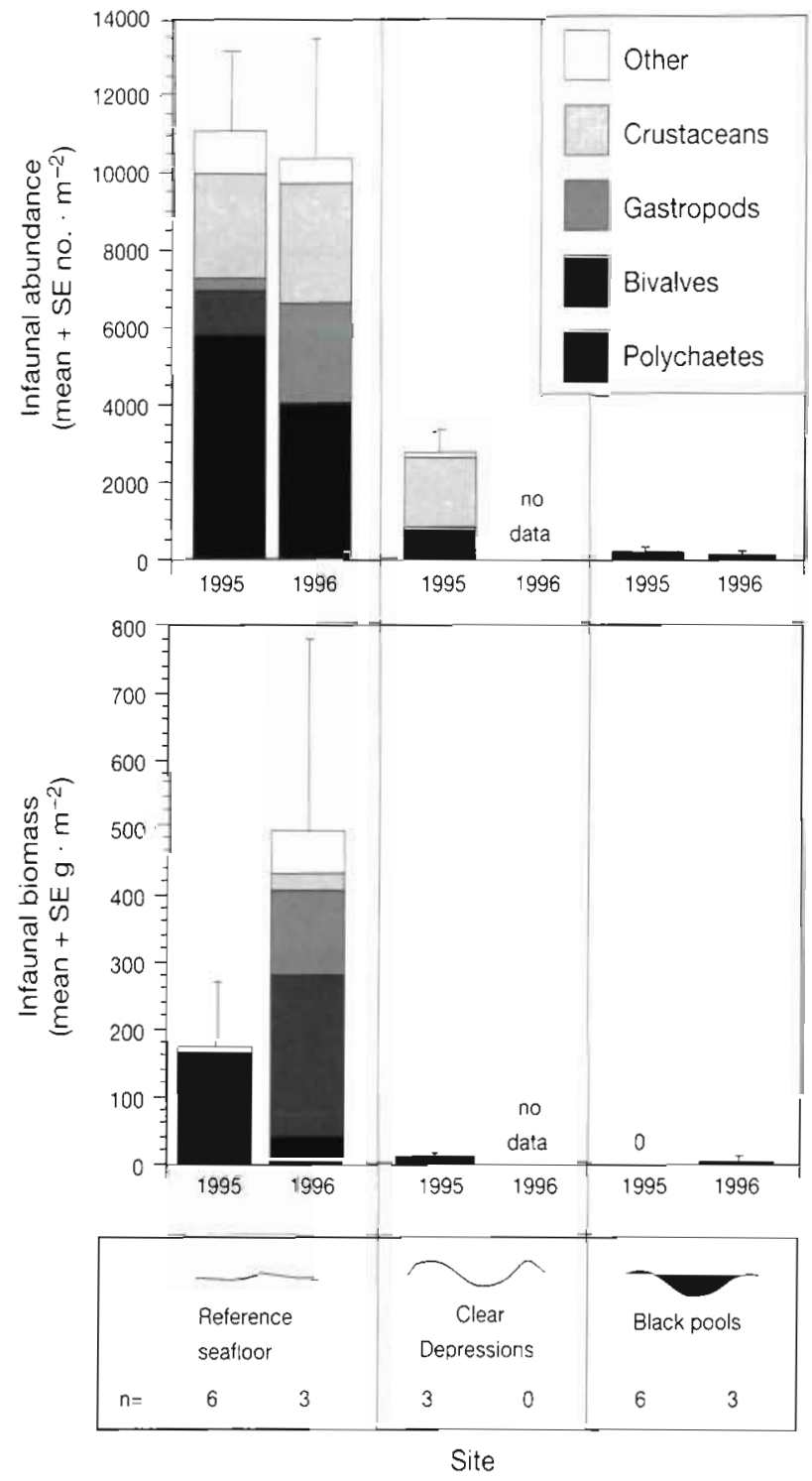

Fig. 6. (a) Abundance and (b) biomass of live infauna found at reference seafloor, clear depression, and black pool sites in 1995, as well as reference and black pool sites resampled in 1996. $n=$ number of sites sampled

Once formed, we believe that the Resolute Bay brine pools persist until disturbed or destabilized. Mixing, however, could occur in several ways. Following the summer break-up of the annual sea ice cover, wind and wave generated mixing is sufficient to turn over the surface waters to a depth of $10 \mathrm{~m}$ and flush the pools, as we observed on 30 July, 1995 (Fig. $8_{8}$ ). Additionally, reduction of brine density by solar heating may destabilize the stratified conditions and contribute to the dissolution of the pools. Alternatively, further ice scour, which is possible as soon as the bay is ice-free, could breach depressions containing pools, allowing drainage of the dense brine downslope. 


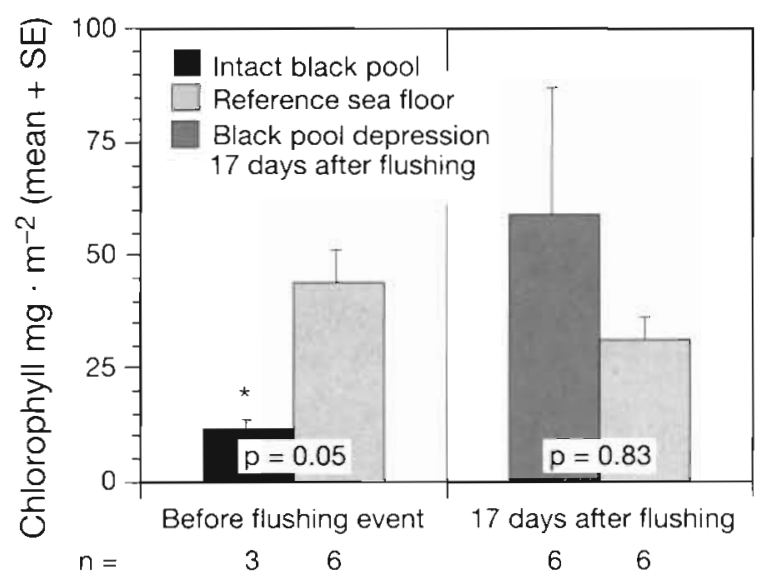

Fig. 7. Benthic diatom biomass (mg chlorophyll $\mathrm{m}^{-2}$, mean + SE) was significantly lower $(*)$ inside black pools before flushing than on surface sediments of reference seafloor sites in 1995. Seventeen days after flushing, diatom biomass was higher inside former black pool depressions than on reference seafloor sediments, but the difference was not significant. $(\mathrm{p}=$ significance level for 1 -tail $t$-test, $\mathrm{n}=$ number of pools, depressions or sites sampled)
After mixing, many of the flushed black pool depressions lose their black color and are reoccupied by epibenthic species, especially scavengers, and early successional infaunal colonists. However, intact depressions can again serve as brine drainage catchment basins the following season (Fig. 82). Indeed, in 1996 we found that black pools had reformed in all 10 of the original 1995 black pool depressions that we were able to relocate. This cycle of brine catchment, hypoxia, benthic mortality, flushing, and partial recovery would tend to keep these depressions perpetually occupied by early successional species (Diaz \& Rosenberg 1995). As a result, benthic community recovery from ice gouging may be slower in protected bays than on exposed coasts, leading to different community spatial patterning and composition.

Unlike the deeper and more persistent seepassociated brine pools (MacDonald et al. 1990, MacDonald \& Fisher 1996), the Arctic brine pools may be much too ephemeral to support chemosynthetic communities. If our conceptual model is correct, however,

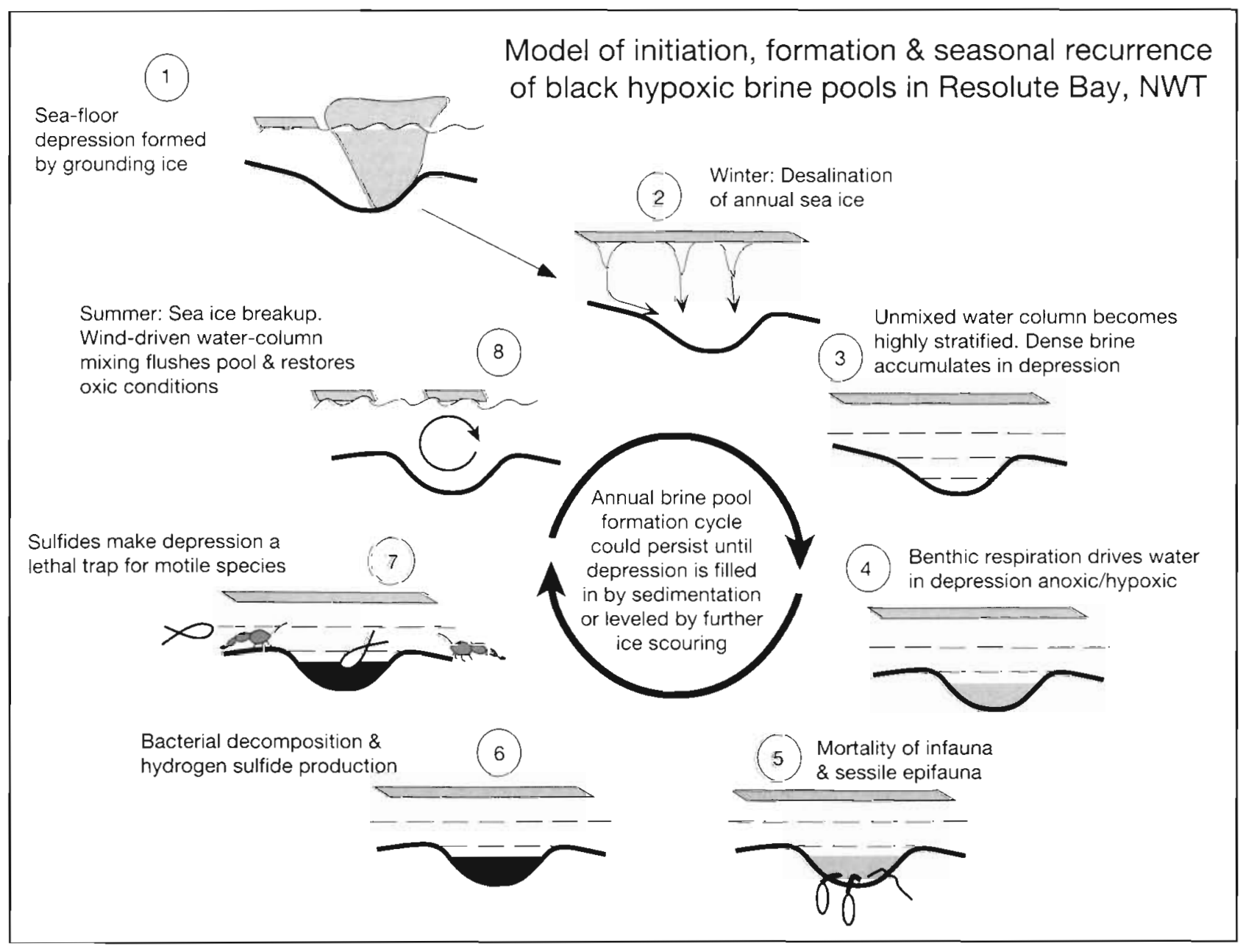

Fig. 8. Conceptual model of initiation, formation, and seasonal recurrence of black hypoxic pools in Resolute Bay, NWT, Canada 
the seasonal recurrence of high latitude shallow water brine pools illustrates how the foot print of a single episodic disturbance event (an ice gouge depression) can repeatedly focus and amplify the biotic impact of an otherwise diffuse, seasonal and entirely different physical event (annual sea-ice desalination). This interaction of disturbance events is analogous to summer fire scars on hillsides amplifying the impact of winter rains, leading to top soil erosion and mud slides (Kinnell et al. 1990, Reid 1994).

Further investigation may show that the occurrence of shallow water hypoxic depressions is widespread and of ecological significance in protected bays throughout northern as well as southern (Bernard 1987) polar environments. Indeed, because both ice scour (Reimnitz et al. 1972a, b) and sea-ice brine drainage (Ackley \& Sullivan 1994, Cavalieri \& Martin 1994) are common phenomena throughout polar regions, the seasonal occurrence of hypoxic brine pools may well be widespread in protected high latitude habitats.

Acknowledgements. We thank D. Bockus, K. Blasco, J. Engel, S. Kim, S. Lamerdin, C. Malzone, and R. Walder for their help in the field. We are also indebted to W. Vincent, W. Broenkow, and S. Tanner for water analysis, S. Blasco and his technical support team for the sidescan sonar record of Resolute Bay, $P$. Hamilton for diatom identification, E. Hendrycks and K. Rodriguez for faunal analyses and G. Cota for help with chlorophyll analysis. S. Alexander and S. Moore provided valuable recommendations for improving the manuscript. Logistical support was provided by the Hamlet of Resolute Bay (H. Kalluk, N. Kalluk, I. Kalluk, and P. Amarualik), The Polar Continental Shelf Project, Natural Resources Canada (B. Hrycyk), and Fisheries and Oceans Canada (H. E. Welch). This project received primary financial support from the National Science Foundation (OPP-9321504) and the Canadian Museum of Nature, and was licensed by the Nunavut Research Institute, Fisheries and Oceans Canada and the Baffin Region Inuit Association.

\section{LITERATURE CITED}

Ackley SF, Sullivan CW (1994) Physical controls on the development and characteristics of Antarctic sea ice biological communities - a review and synthesis. Deep Sea Res I 41: $1583-1604$

Bermard JM (1987) Foraminiferal biotopes in Explores Cove, McMurdo Sound, Antarctic. J Foram Res 17:286-297

Bright TJ, La Rock PA, Lauer RD, Brooks JM (1980) A brine seep at the east Flower Garden Bank, northwest Gulf of. Mexico. Int Rev Ges Hydrobiol 65:321-335

Brooks JM, Bright TJ, Bernard BB, Schwab CR (1979) Chemical aspects of a brine pool at the east Flower Garden Bank, northwest Gulf of Mexico. Limnol Oceanogr 24: 735-745

Bydder EL, Holdsworth R (1977) Lake Vanda (Antarctica) revisited. NZ J Geol Geophys 20:1027-1032

Cary CF, Fry B, Felbeck H, Vetter RD (1989) Multiple trophic resources for a chemoautotrophic community at a cold water brine seep at the base of the Florida Escarpment Mar Biol 100:411-418
Cavalien DJ, Martin S (1994) The contribution of Alaskan, Siberian, and Canadian coastal polynyas to the cold halocline layer of the Arctic Ocean. J Geophys Res 99: $18343-18362$

Diaz RJ, Rosenberg R (1995) Marine benthic hypoxia: a review of its ecological effects and the behavioral responses of benthic macrofauna. Oceanogr Mar Biol Annu Rev 33: $245-303$

Faganeli J, Avcin A, Fanuko N, Malej A, Turk V, Tusnik P, Vriser B, Vukovic A (1985) Bottom layer anoxia in the central part of the Gulf of Trieste in the late summer of 1983. Mar Pollut Bull 16:75-78

Gallagher JB, Burton HR (1988) Seasonal mixing of Ellis Fjord, Vestfold Hills, East Antarctica. Estuar Coast Shelf Sci 27:363-380

Harper DE Jr, McKinney LD, Salzer RR, Case RJ (1981) The occurrence of hypoxic bottom water of the upper Texas Coast and its effect on the benthic biota. Contrib Mar Sci $24: 53-79$

Hoare RA (1966) Problems of heat transfer in Lake Vanda, a density stratified Antarctic lake. Nature 210:787-789

Hovland M, Judd AG (1988) Seabed pockmarks and seepages. Graham and Troutman, Boston

Kinnell PIA, Chartre CJ, Watson CL (1990) The effects of fire on the soil in a degraded semi-arid woodland. II. Susceptibility of the soil to erosion by shallow rain-impacted flow. Aust J Soil Res 28:779-794

Lewis EL (1981) Brine drainage from shallow Arctic waters Paper presented at the American Geophysical Union, San Francisco, California. EOS 62:901.

Lund JWG, Kipling C, LeCren ED (1958) The inverted microscope method of estimating algal numbers and the statistical basis of estimations by counting. Hydrobiologia 11. $143-170$

MacDonald IR (1992) Sea-floor brine pools affect behavior, mortality, and preservation of fishes in the Gulf of Mexico: Lagerstätten in the making? Palaios 7:383-387

MacDonald IR, Fisher C (1996) Life without light. Nat Geogr 190:86-97

MacDonald IR, Reilly JF II, Guinasso NL Jr, Brooks JM, Carney RS, Bryant WA, Bright TJ (1990) Chemosynthetic mussels at a brine-filled pockmark in the northern Gulf of Mexico. Science 248:1096-1099

Reid R (1994) After the fire. (California geologists find fault with erosion-control measures intended to prevent landslides and flooding.) Am Sci 82:20-21

Reimnitz E, Barnes PW, Forgatsch TC, Rodeick CA (1972a) Influence of grounding ice on the Arctic shelf of Alaska. Marine Geology 13:323-334

Reimnitz E, Barnes PW, Toimil LJ, Melchoir J (1972b) Ice gouge recurrence and rates of sediment reworking, Beaufort Sea. Geology 5:405-408

Shokes RF, Trabant PK, Presely BJ, Reid DF (1977) Anoxic, hypersaline basin in the northern Gulf of Mexico. Science 196:1443-1446

Sournia A (1978) Phytoplankton manual. United Nations Educational, Scientific, and Cultural Organization, Paris

Welch HE, Kalff J (1974) Benthic photosynthesis and respiration in Char Lake. J Fish Res Bd Can 31:609-620

Welch HE, Kalff J (1975) Marine metabolism at Resolute Bay, Northwest Territories. Circumpolar Conference on Northern Ecology Il. National Research Council of Canada, Ottawa, p 69-75

Welch HE, Siferd TD, Breucker P (1997) Marine zooplanktonic and benthic community respiration rates at Resolute, in the Canadian high Arctic. Can J Fish Aquat Sci 54:1-7 